\title{
Evaluation of Serum Creatine Kinase (CK-MB) Activity in Murrah Buffaloes and Nellore Sheep Exposed to Slaughter Stress
}

\author{
Deepa Pathipati $^{1 *}$, K. Jayasri ${ }^{2}$, B. Supriya ${ }^{3}$ and A. V. N. Siva Kumar ${ }^{1}$ \\ ${ }^{1}$ Department of Veterinary Physiology, ${ }^{2}$ Department of Veterinary Biochemistry, \\ ${ }^{3}$ Department of Veterinary Anatomy, College of Veterinary Science, \\ S.V.V.U, Tirupati-517502, India \\ *Corresponding author
}

\begin{tabular}{|c|c|}
\hline & A B S T R A C T \\
\hline & \multirow{9}{*}{$\begin{array}{l}\text { The objective of the current study was to determine and compare the effects } \\
\text { of pre slaughter stress on serum creatine kinase activity in Murrah buffaloes } \\
\text { and Nellore sheep. Whole blood samples collected from a total of } 170 \\
\text { buffaloes and sheep were used in this study. Samples were collected from } \\
\text { two groups of animals which include: 1) one day before slaughter and 2) } \\
\text { few seconds prior to exsanguination to measure the concentration of } \\
\text { creatine kinase (CK-MB) in serum. From this study we observed that CK- } \\
\text { MB activity was significantly higher in the samples collected just before } \\
\text { exsanguination in both species than in samples collected one day before } \\
\text { slaughter. Although the magnitude of increase was slightly higher in } \\
\text { buffaloes than in sheep, however indicates that preslaughter stress response } \\
\text { affects serum creatine kinase activity in both the species. }\end{array}$} \\
\hline Keywords & \\
\hline & \\
\hline Slaughter stress, & \\
\hline & \\
\hline Article Info & \\
\hline $\begin{array}{l}\text { Accepted: } \\
10 \text { April } 2020\end{array}$ & \\
\hline $\begin{array}{l}\text { Available Online: } \\
10 \text { May } 2020\end{array}$ & \\
\hline & \\
\hline
\end{tabular}

\section{Introduction}

Livestock is one of the fastest growing agricultural subsectors in India as it plays a key role in mitigating the risks and uncertainties involved in income generation through crop production. India accounts for $58 \%$ of world buffalo population according to $19^{\text {th }}$ livestock census. whereas sheep population is 65.07 millions and are preferred over other species in especially in developing countries like India because of its multifaceted utility for wool, meat, milk, skin and manure apart from its vast genetic resource i.e with 42 breeds of sheep in India. Due to the increased consumption and 
improved marketing trends, buffaloes and sheep became the prominent species in the meat production sector. But the stress experienced due to pre slaughter handling and related operations is gaining importance because of their negative effects on the final quality of the meat (Lowe et al., 2001; Miranda-de la Lama et al., 2010; Vimiso and Muchenje, 2013).

A slaughter house presents a multi factorial stressor for the meat producing animals. The animals are exposed to a variety of stressors in and around slaughter i.e. climate, temperature, nutrition, during transport, in lairage and even up to exsanguination that triggers many physiological reactions which might result in variations of haematological (Kour et al., 2015), biochemical (Mccorry, 2007; Werner and Gallo, 2008; Micera et al., 2010) and oxidative stress parameters (Mader, 2003; Schaefer et al., 2001; O’Neill et al., 2006; Fazio et al., 2008; Werner and Gallo, 2008; Micera et al., 2010; Anil, 2012; Svete et al., 2012; Ekiz et al., 2013; Loudon et al., 2019).

Among such factors creatine kinase (CK) is a vital and sensible indicator in the determination of muscular activity, muscle damage and fatigue caused by physical exertion in animals as it is expressed cytoplasm and mitochondria of different tissues mostly in skeletal muscle, brain and heart (Stull and Rodiek, 2000; Tadich et al., 2005; Hambrecht et al., 2005; Werner and Gallo, 2008; Miranda-de la Lama et al., 2010; Ekiz et al., 2012) and muscle damage subsequently affects meat quality (Brancaccia et al., 2010; Baird et al., 2012; Gebresenbet et al., 2012; Koch et al., 2014; Nakyinsige et al., 2014). Other than CK, blood activities of other enzymes such as lactate dehydrogenase (LDH), superoxide dismutase (SOD), glutathione peroxidase (GPX), alanine aminotransferase (ALT) and aspartate aminotransferase (AST) also are elevated after muscle damage (Valentine and McGavin, 2013). The extent of tissue damage during handling is also indicated by the increased levels of CK in the blood (European Food Safety Authority (EFSA), 2004; Tackett et al., 2008; Grandin, 2010; Minka and Ayo, 2010; Nakyinsige et al., 2013). Accordingly the present work was undertaken to measure the creatine kinase activity with respect to pre slaughter stress in Murrah buffaloes and Nellore sheep.

\section{Materials and Methods}

\section{Animal sampling}

In this study the blood samples were collected from the buffaloes and sheep to compare the creatine kinase activity with respect to stressful events in and around slaughter. The blood samples were collected from Murrah buffaloes brought to the slaughter house in kabela area of Vijayawada and from Nellore sheep in local slaughter house of Tirupati.

Blood samples were collected from jugular vein of each animal one day before slaughter and the other is just few seconds before exsanguination from the same group of animals. A total of 170 animals (buffaloes: $n=65$ and sheep: $n=105$ ) were included in this study.

\section{Collection and preparation of blood samples for serum creatine kinase (CK- MB) activity estimation}

The whole blood samples were collected from jugular vein of both the species in the $4 \mathrm{ml}$ clot activator (A-Vac tubes; Lot No: 2019/05/CA) vacutainer tubes to extract serum. A centrifuge machine (Model no: 5403; Remi Instruments) was used to centrifuge blood samples at 3000rpm for 15 minutes. 
Serum was then separated carefully and inserted in to $2.0 \mathrm{~mL}$ eppendorf tubes using pipettes and stored at $-20^{\circ} \mathrm{C}$ until used. Serum Creatine kinase (CK-MB) activity was measured by Immuno inhibition method in A15 random access analyzer (Biosystems, Spain) using Creatine kinase detection kit (CK-MB kit; catalogue no: 12566, Biosystems, Spain) according to the manufacturer instructions.

\section{Statistical analysis}

Means and standard deviation between the samples collected one day before slaughter and just prior to exsanguination was analysed through paired t-test by using SPSS 20 software. The significant differences of creatine kinase concentrations were considered significant if value of $\mathrm{P}$ is less than 0.05 .

\section{Results and Discussion}

The creatine kinase concentrations were evaluated in two groups of serum samples in each species. From the results it is observed that the creatine kinase concentration was significantly higher in the samples collected just before exsanguination in both species (Fig. 3.1 and 3.2). Among the two species studied the creatine kinase level was significantly higher in buffaloes than in sheep in both the groups $(266.34 \mathrm{U} / \mathrm{L}$ Vs $221.86 \mathrm{U} / \mathrm{L}$ a day before slaughter and 530.38U/L Vs 483.50U/L at exsanguination). From this study we conclude that the creatine kinase levels increase in response to preslaughter stress in both buffaloes and sheep although the magnitude of increase was significantly higher in buffaloes among the two species studied.

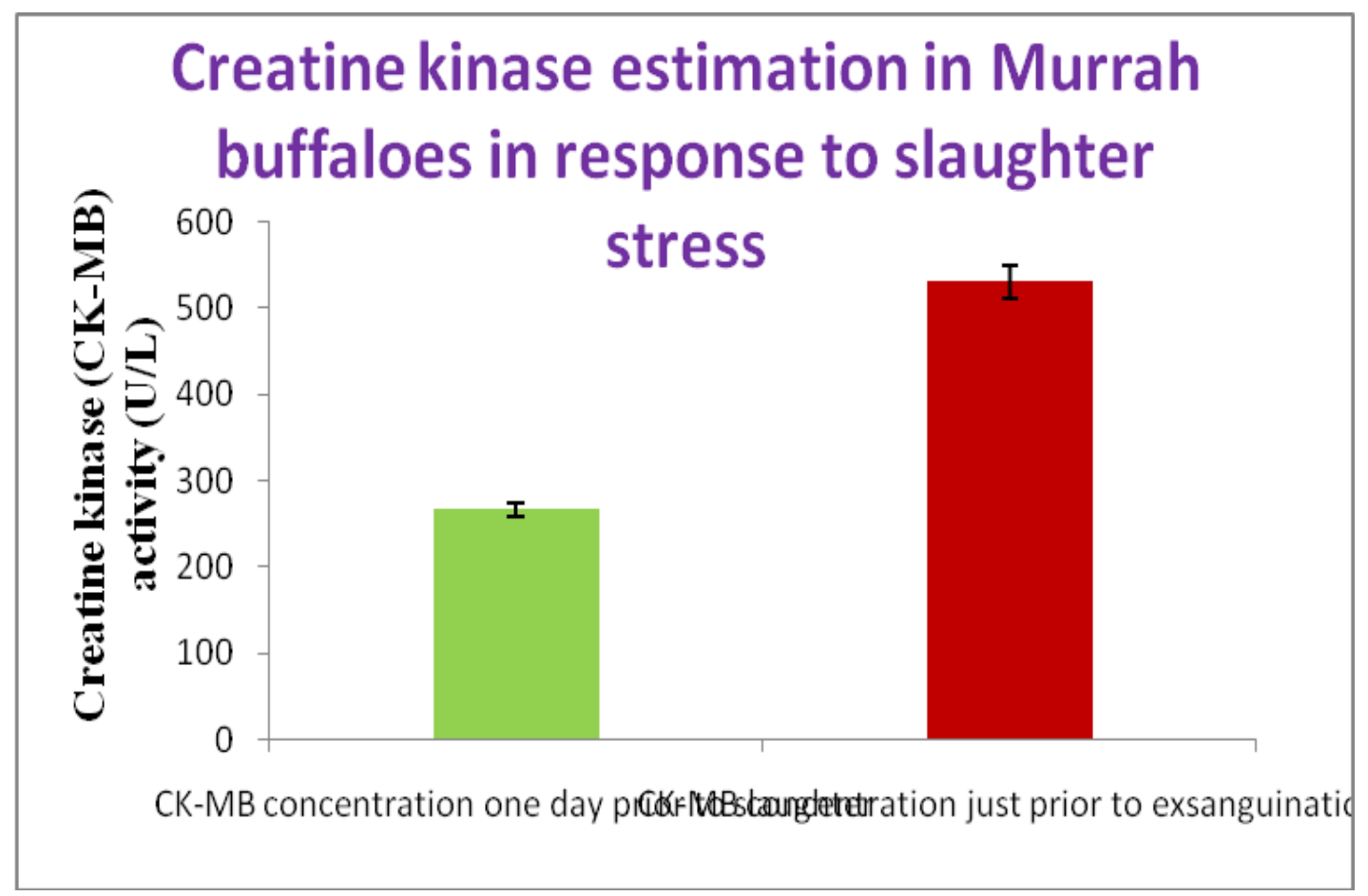

Fig.1 Bar diagram representing the creatine kinase activity in Murrah buffaloes in the serum samples collected one day before slaughter and just before exsanguination 


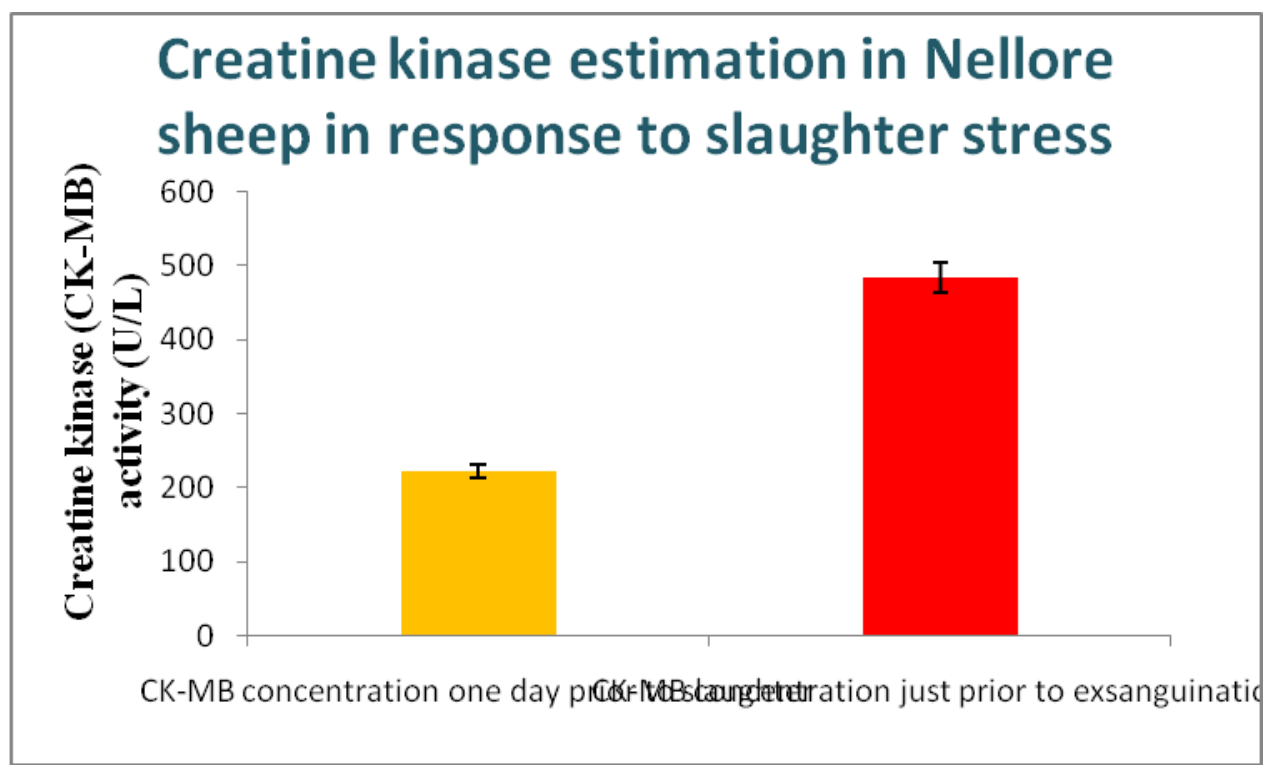

Fig.2 Bar diagram representing the creatine kinase activity in Nellore sheep in the serum samples collected one day before slaughter and just before exsanguination.

In the animal production sector preslaughter operations impose high levels of stress on the animals that leads to adverse changes in the storage life and quality of the meat (Prost 1981). Creatine kinase is a key enzyme which serves as a haematological marker of muscle damage whose activity increase significantly in response to muscle damage or injuries due to excess strain (Procajło 2006). Such elevated levels of creatine kinase activity is a sensible indicator for the recent muscle damage due to its short half-life that can be related to the stress experienced by animals during preslaughter handling in the investigated animals.

In this study, a significant increase in serum creatine kinase activity obtained one day before slaughter in comparison with serum samples at the time of exsanguination suggests a rigorous stress response in both buffaloes and sheep. Previous reports indicated that the physical stress in and around slaughter might result from holding the animal to drive from lairage to stunning area and restraining them for stunning could lead to muscle damage and therefore subsequently increased liberation of serum muscle enzymes (Stull and Rodiek, 2000; Van de Water et al., 2003; Tadich et al., 2005; Loudon et al., 2019). Also not only the transportation but the feed deprivation and adverse environmental factors might infer the changes in the muscles which could bring about discharge of stress enzymes (Baird et al., 2012; Teke et al., 2014; Loudon et al., 2019).

The elevation of CK activity observed in the current study could be ascribed to the increased permeability in the muscle membrane due to disruption of muscle due to traumatic events or physical stress (Tadich et al., 2005; Bórnez et al., 2009; De la Fuente et al., 2010; Minka and Ayo, 2010; Baird et al., 2012; Loudon et al., 2019). Moreover Van de Water et al., 2003 reported that mounting and butting behaviours expressed during the lairage period resulted in high $\mathrm{CK}$ activity determined at the time of bleeding. In this study the magnitude of increase in the creatine kinase activity in the serum samples is significantly higher values in in buffaloes than in sheep with respect to samples collected just before exsanguination which might be due to enhanced activation of the 
passive fluxes via alpha 1 and 2 adrenergic receptors (Moratinos and Reverte, 1993; Chulayo and Muchenje, 2013) in buffaloes when compared to sheep (Shaw and Tume, 1992) in response to stunning and bleeding. From the current study, it is concluded that elevated levels of creatine kinase activity is due to stress response incurred as a consequence of pre-slaughter events in both buffaloes and sheep.

Out of the two species studied the creatine kinase concentration is significantly higher in buffaloes at exsanguination than in sheep which is a clear indication that buffaloes are exposed to more stressful events in and around slaughter than sheep. Further other enzymatic markers associated with stress needs to be evaluated in these breeds of buffaloes and sheep in future to undertake the proper management practices to reduce stress and therefore the quality of meat.

\section{Acknowledgement}

The authors thank K. Padmaja, Professor, Department of Veterinary Biochemistry, College of Veterinary Science, S.V.V.U, Tirupati for her assistance in providing the laboratory facilities to conduct this work.

\section{References}

Anil, M. H. (2012). Effects of slaughter method on carcass and meat characteristics in the meat of cattle and sheep. EBLEX - A Division of the Agriculture and Horticulture Development Board, UK, 1-73.

Baird, M. F., Graham, S. M., Baker, J. S., \& Bickerstaff, G. F. (2012). Creatinekinase-and exercise-related muscle damage implications for muscle performance and recovery. Journal of nutrition and metabolism, 2012.

Bórnez, R., Linares, M. B., \& Vergara, H. (2009). Haematological, hormonal and biochemical blood parameters in lamb: effect of age and blood sampling time. Livestock Science, 121(2-3), 200206.

Brancaccio, P., Lippi, G., \& Maffulli, N. (2010). Biochemical markers of muscular damage. Clinical chemistry and laboratory medicine, 48(6), 757767.

Chulayo, A. Y., \& Muchenje, V. (2013). The effects of pre-slaughter stress and season on the activity of plasma creatine kinase and mutton quality from different sheep breeds slaughtered at a smallholder abattoir. Asian-Australasian journal of animal sciences, 26(12), 1762.

De la Fuente, J., Sánchez, M., Pérez, C., Lauzurica, S., Vieira, C., De Chávarri, E. G., \& Díaz, M. T. (2010). Physiological response and carcass and meat quality of suckling lambs in relation to transport time and stocking density during transport by road. Animal, 4(2), 250-258.

Ekiz, B., Ergul Ekiz, E., Kocak, O., Yalcintan, H., \& Yilmaz, A. (2012). Effect of preslaughter management regarding transportation and time in lairage on certain stress parameters, carcass and meat quality characteristics in Kivircik lambs. Meat Science, 90(4), 967-976.

Ekiz, E., \& Yalcintan, H. (2013). Comparison of certain haematological and biochemical parameters regarding preslaughter stress in Saanen, Maltese, Gokceada and hair goat kids. İstanbul Üniversitesi Veteriner Fakültesi Dergisi, 39(2), 189-196.

European Food Safety Authority (EFSA). (2004). Opinion of the scientific panel on animal health and welfare on a request from the commission related to the welfare of animals during transport. Question number: EFSA-Q-2003-094. European Food Safety Authority Journal, 44, 1-36.

Fazio, E., Medica, P., Aronica, V., Grasso, L., $\&$ Ferlazzo, A. (2008). Circulating $\beta$ - 
endorphin, adrenocorticotrophic hormone and cortisol levels of stallions before and after short road transport: stress effect of different distances. Acta Veterinaria Scandinavica, 50(1), 6.

Gebresenbet, G., Wikner, I., Bobobee, E. Y. H., Maria, G., \& Villarroel, M. (2012). Effect of transport time and handling on physiological responses of cattle. Journal of Agricultural Science and Technology. A, 2(6A), 800.

Grandin, T. (2010). Auditing animal welfare at slaughter plants. Meat Science, 86(1), 56-65.

Hambrecht, E., Eissen, J. J., Newman, D. J., Smits, C. H. M., Den Hartog, L. A., \& Verstegen, M. W. A. (2005). Negative effects of stress immediately before slaughter on pork quality are aggravated by suboptimal transport and lairage conditions. Journal of animal science, 83(2), 440-448.

Koch, A. J., Pereira, R., \& Machado, M. (2014). The creatine kinase response to resistance exercise. $J$ Musculoskelet Neuronal Interact, 14(1), 68-77.

Kour, S., Devi, J., Kour, K., Chakraborty, D., Ganai, A. W., Khajuria, P., \& Zargar, R. (2015). Effect of thermal stress on haematological parameters and enzymatic activities in two breeds of goat after thermal stress. Journal of Animal Research, 5(4), 855-862.

Loudon, K. M., Tarr, G., Pethick, D. W., Lean, I. J., Polkinghorne, R., Mason, M, Dunshea, F. R., Gardner, G. E \& McGilchrist, P. (2019). The use of biochemical measurements to identify pre-slaughter stress in pasture finished beef cattle. Animals, 9(8), 503.

Lowe, T. E., Cook, C. J., Ingram, J. R., \& Harris, P. J. (2001). Impact of climate on thermal rhythm in pastoral sheep. Physiology \& behavior, 74(4-5), 659-664.

Mader, T. L. (2003). Environmental stress in confined beef cattle. Journal of animal science, 81(14_suppl_2), E110-E119.

McCorry, L. K. (2007). Physiology of the autonomic nervous system. American journal of pharmaceutical education, 71(4).

Micera, E., Albrizio, M., Surdo, N. C., Moramarco, A. M., \& Zarrilli, A. (2010). Stress-related hormones in horses before and after stunning by captive bolt gun. Meat science, 84(4), 634-637.

Minka, N. S., \& Ayo, J. O. (2010). Physiological responses of food animals to road transportation stress. African journal of Biotechnology, 9(40), 66016613.

Miranda-de la Lama, G. C., Rivero, L., Chacón, G., Garcia-Belenguer, S., Villarroel, M., \& María, G. A. (2010). Effect of the pre-slaughter logistic chain on some indicators of welfare in lambs. Livestock Science, 128(1-3), 52-59.

Moratinos, J., \& Reverte, M. (1993). Effects of catecholamines on plasma potassium: the role of alpha- and beta- adrenoceptors. Fundamental \& clinical pharmacology, 7(3-4), 143 153.

Nakyinsige, K., Sazili, A., Aghwan, Z., Zulkifli, I., Goh, Y., \& Fatimah, A. (2013). Changes in blood constituents of rabbits subjected to transportation under hot, humid tropical conditions. AsianAustralasian Journal of Animal Sciences, 26(6), 874-878.

Nakyinsige, K., Sazili, A., Zulkifli, I., Goh, Y., Fatimah, A., \& Sabow, A. (2014). Influence of gas stunning and halal slaughter (no stunning) on rabbits welfare indicators and meat quality. Meat Science, 98, 701-708.

O’Neill, H., Webb, E., Frylinck, L., \& Strydom, P. (2006). The stress responsiveness of three different beef breed types and the effect on ultimate $\mathrm{pH}$ and meat colour. Paper presented at the 52nd International Congress of Meat Science and Technology: Harnessing and exploiting global opportunities.

Procajło, A. (2006). Diagnostic efficacy of indicators of muscle damage in sled 
dogs during training. Medycyna Weterynaryjna, 62(3), 306-310.

Schaefer, F., Chen, Y., Tsao, T., Nouri, P., \& Rabkin, R. (2001). Impaired JAK-STAT signal transduction contributes to growth hormone resistance in chronic uraemia. Journal of Clinical Investigation, 108(3), 467-475.

Shaw, F. D., \& Tume, R. K. (1992). The assessment of pre-slaughter and slaughter treatments of livestock by measurement of plasma constituents - a review of recent work. Meat science, 32(3), 311-329.

Stull, C. L., \& Rodiek, A. V. (2000). Physiological responses of horses to 24 hours of transportation using a commercial van during summer conditions. Journal of animal science, 78(6), 1458-1466.

Svete, A. N., Čebulj-Kadunc, N., Frangež, R., \& Kruljc, P. (2012). Serum cortisol and haematological, biochemical and antioxidant enzyme variables in horse blood sampled in a slaughterhouse lairage, immediately before stunning and during exsanguination. Animal, 6(8), $\quad$ 13001306.

Tackett, J., Reynolds, A. S., \& Dickerman, R. D. (2008). Enzyme elevations with muscle injury: know what to look for!. British journal of clinical pharmacology, 66(5), 725.

Tadich, N., Gallo, C., Bustamante, H.,
Schwerter, M., \& Van Schaik, G. (2005). Effects of transport and lairage time on some blood constituents of Friesian-cross steers in Chile. Livestock Production Science, 93(3), 223-233.

Teke, B., Akdag, F., Ekiz, B., \& Ugurlu, M. (2014). Effects of different lairage times after long distance transportation on carcass and meat quality characteristics of Hungarian Simmental bulls. Meat Science, 96(1), 224-229.

Valentine, B.A.; McGavin, M.D. (Eds.). (2013). Bases da patologia em veterinária. Rio de Janeiro: Elsevier, 1344.

Van De Water, G., Verjans, F., \& Geers, R. (2003). The effect of short distance transport under commercial conditions on the physiology of slaughter calves; $\mathrm{pH}$ and colour profiles of veal. Livestock Production Science, 82(2-3), 171-179.

Vimiso, P., \& Muchenje, V. (2013). A survey on the effect of transport method on bruises, $\mathrm{pH}$ and colour of meat from cattle slaughtered at a South African commercial abattoir. South African Journal of Animal Science, 43(1), 105111.

Werner, M., \& Gallo, C. (2008). Effects of transport, lairage and stunning on the concentrations of some blood constituents in horses destined for slaughter. Livestock Science, 115(1), 9498.

\section{How to cite this article:}

Deepa Pathipati, K. Jayasri, B. Supriya and Siva Kumar. A. V. N. 2020. Evaluation of Serum Creatine Kinase (CK-MB) Activity in Murrah Buffaloes and Nellore Sheep Exposed to Slaughter Stress. Int.J.Curr.Microbiol.App.Sci. 9(05): 1308-1314. doi: https://doi.org/10.20546/ijcmas.2020.905.145 